\title{
The Influence of Dietary Protein on the Synthesis of Vasoactive Substances in Subtotally Nephrectomized Spontaneously Hypertensive Rats
}

\author{
Koichi Hayashi, M.D., Hiromichi Suzuki, M.D., \\ Hiroshige Katsumata, M.D., Akira Ohrshi, M.D., \\ Hidetomo Nakamoto, M.D., and Takao Saruta, M.D.
}

\begin{abstract}
Summary
The effects of dietary protein alterations on the synthesis of prostaglandins and kallikrein were examined in subtotally nephrectomized spontaneously hypertensive rats. Three diets containing 40, 24 and $8 \%$ protein were prepared. After subtotal nephrectomy, rats were given one of the three diets for the next 12 weeks. During the study, systolic blood pressure, urinary excretions of protein, 6-keto-prostaglandin Fl $\alpha$, thromboxane $B_{2}$ and kallikrein were measured every 2 weeks. Although the diets did not prevent the further elevation of systolic blood pressure, the rats on the low protein diet displayed lower serum creatinine levels and urinary protein levels. The urinary excretion of thromboxane $B_{2}$ was unaffected by the amount of dietary protein, but the urinary excretion of 6-keto-prostaglandin $\mathrm{Fl} \alpha$ was lower in the low protein diet group. Furthermore, the urinary excretion of kallikrein increased significantly in rats on high protein diet. These results suggest that manipulation of dietary protein may alter the natural course of renal failure induced by subtotal nephrectomy in spontaneously hypertensive rats.
\end{abstract}

\section{Abbreviations :}

SHR = spontaneously hypertensive rats; $\mathrm{STD}=$ standard diet; $\mathrm{LP}=$ low protein; $\mathrm{HP}=$ high protein; $\mathrm{CTR}=$ control.

\section{Additional Indexing Words:}

Prostaglandins Kallikrein Renin-angiotensin system

TUMEROUS investigations have demonstrated that dietary protein in1 fluences the natural course of chronic renal failure in both humans ${ }^{11}$ and experimental animals. ${ }^{21,31}$ Dietary protein restriction in early renal failure slows the progression of functional deterioration and postpones dialysis. ${ }^{4}$ In

From the Department of Internal Medicine, School of Medicine, Keio University, Tokyo, Japan.

Address for reprints: Takao Saruta, M.D., Department of Internal Medicine, School of Medicine, Keio University, 35 Shinanomachi, Shinjuku-ku, Tokyo 160, Japan.

Received for publication January 5, 1989.

Accepted April 21, 1989. 
subtotally nephrectomized rats, a protein overload accelerates the progression of renal failure, while the restricted intake retards or even halts the development of renal damage. ${ }^{5)}$ Brenner et $a^{6 /}$ recently demonstrated that a limited intake of dietary protein corrects the "maladaptive hyperfiltration" produced by renal ablation and lessens the structural abnormalities in remnant glomeruli, suggesting that intrarenal hypertension might be responsible for progressive glomerular injury.

It is well known that renal diseases advance more rapidly when they are superimposed on essential hypertension and that systemic hypertension aggravates underlying renal diseases in chronic renal failure. ${ }^{7}$ Changes in intrarenal hemodynamics in the glomeruli may suggest participation in the evolution of renal failure." Although both protein loading and hypertension may alter the intra-glomerular hemodynamics, interactions between these factors have not been previously evaluated.

In recent years, many investigators have discussed the interrelations between renal circulation and vasoactive substances, such as prostaglandins and kallikrein. ${ }^{81-10)}$ These discussions were prompted by the observations that renal prostaglandin and kallikrein synthesis are changed in human and experimental animals with different degrees of renal insufficiency. We have investigated the effects of dietary protein on the synthesis of the vasoactive substances in spontaneously hypertensive rats with subtotal renal ablation. These data assist with the elucidation of the role of renal vasoactive substances in hypertensive animals with chronic renal failure.

\section{METHODS}

Preparation of the model:

Spontaneously hypertensive rats of the Okamoto-Aoki strain (SHR), weighing 180 to $200 \mathrm{~g}$, were used. The animals underwent 5/6 nephrectomy. Under ether anesthesia the upper and lower poles of the left kidney were resected. The contralateral nephrectomy was performed 1 week later. The sham-operated control animals were closed after exposure of the kidneys. Two weeks after subtotal nephrectomy, blood was obtained through a polyethylene tube (PE-10, Intramedic, Japan) in the femoral vein to measure the serum creatinine.

\section{Experimental protocol:}

All rats received a standard diet (STD : $24 \%$-protein $/ 0.39 \%$-sodium) during 2 weeks following surgery, thereafter the nephrectomized rats were randomly allocated to the following 3 groups: (1) SHR-STD group $(n=8)$ 
(STD: 24\% protein), (2) SHR-HP group ( $\mathrm{n}=9$ ) (HP: 40\%-protein), (3) SHR-LP group $(n=10)$ (LP: $8 \%$ protein). Sham-operated rats were fed the standard diet throughout the experimental period [SHR-GTR group $(\mathrm{n}=7)]$. The rats were housed in individual metabolic cages with controlled temperature $\left(25^{\circ} \mathrm{C}\right)$ and a light cycle of 12 hours. The three diets (CLEA Japan, Inc., Tokyo, Japan) were isocaloric (345 Kcal/100 g) and contained equal amounts of mineral supplements (sodium: 0.39\%, potassium: $0.98 \mathrm{~g} / 100 \mathrm{~g}$, calcium: $0.9 \mathrm{~g} / 100 \mathrm{~g}$, phosphate: $1.06 \mathrm{~g} / 100 \mathrm{~g}$, magnesium: $0.3 \mathrm{~g} / 100 \mathrm{~g}$ ). Food consumption was made constant across groups.

\section{Measurement:}

Body weight and urine volume were measured at 2 week intervals. Systolic blood pressure was recorded from the tail of conscious rats, using an electrosphygmomanometer (Natsume Inc., Tokyo, Japan). Urinary protein excretion was measured according to the method of Lowry et al. ${ }^{11}$ The radioimmunoassays for 6-keto-prostaglandin Fl $\alpha$ (6-keto-PGF $1 \alpha$ ) and thromboxane $\mathrm{B}_{2}\left(\mathrm{TxB}_{2}\right)$ are described in a previous publication, ${ }^{12)}$ as modified from the method of Dray et al. ${ }^{13}$ ) Briefly, the samples were acidified ( $\mathrm{pH} 3$ ) with citric acid and extracted twice with a mixture of cyclohexane / ethylacetate $(1: 1)$. The organic phase was evaporated to dryness at $37^{\circ} \mathrm{C}$ and then dissolved in solvent I (benzene/ethylacetate/methanol, 60:40:2), which was applied to silicic acid (100 mesh Mallinckrodt) open columns equilibrated with solvent II (benzene/ethylacetate, 60:40). The columns were developed serially with solvent I, solvent II and solvent III (benzene / ethylacetate / methanol, 60: 40:20). $\mathrm{TxB}_{2}$ and 6-keto-PGF1 $\alpha$ were eluted with solvent II and III, respectively. Each eluate was evaporated to dryness, followed by redissolution in $0.1 \mathrm{M}$ phosphate buffer $\left(\mathrm{pH} 7.4 ; 0.9 \% \mathrm{NaCl}, 0.1 \% \mathrm{NaN}_{3}, 0.1 \%\right.$ gelatin). The antisera and PG standards were gifts from Ono Pharmaceutical Co. (Osaka, Japan) and radiolabeled PGs were purchased from New England Nuclear (Boston, USA). Urinary kallikrein was measured by the method of Morita et al, ${ }^{14)}$ using 7-amino-4-methylcoumarin amide (Sigma Chemical Co., St. Louis, USA) as a substrate. At both 12 and 22 weeks of the experiment, blood was collected through polyethylene catheters (PE-10, Intramedic., Japan) in the femoral and jugular vein, respectively. The hematocrit, total protein, serum creatinine, serum sodium and potassium and plasma renin activity (PRA) were determined. PRA was determined by the method of Habcr et al. ${ }^{15}$ ) Determination of plasma electrolytes (sodium and potassium) were made by flame photometry, and plasma creatinine was measured by a modification of the Jaffe reaction. ${ }^{16)}$ 
Statistical analysis:

The results are presented as means \pm SE. Statistical evaluation was performed by one-way analysis of variance, followed by Student's unpaired ttest, and $p$ values less than 0.05 were considered significant.

\section{RESULTS}

Basic data from these experiments are summarized in Table I. There were no significant differences in body weight as a function of diet (Table I). Urine volume was significantly increased by the administration of the high protein diet and was significantly decreased by low protein diet, compared to rats on the standard diet. Hematocrit values were significantly lower in the nephrectomized groups than in the sham-operated group. The HP group revealed a depressed hematocrit value, but the hematocrit was significantly higher in the LP group than in corresponding STD group. Serum total protein, plasma renin activity (PRA) and serum electrolytes did not differ significantly as a function of dietary protein. Finally, dietary protein did not affect the behavior of systolic pressure in nephrectomized rats (Fig. 1).

Table I. Effects of Dietary Protein on Hematocrit, Total Protein, Serum Sodium and Potassium and Plasma Renin Activity and Body Weight

\begin{tabular}{|c|c|c|c|c|c|c|c|c|}
\hline \multirow{3}{*}{ Measurements } & \multicolumn{2}{|c|}{$\begin{array}{l}\text { sham } \sim \text { operated } \\
(\mathrm{CTR})(\mathrm{n}=7)\end{array}$} & \multicolumn{2}{|c|}{$\begin{array}{l}\text { standard diet } \\
(\mathrm{STD})(\mathrm{n}=8)\end{array}$} & \multicolumn{2}{|c|}{$\begin{array}{l}\text { high protein } \\
\text { (HP) }(\mathrm{n}=9)\end{array}$} & \multicolumn{2}{|c|}{$\begin{array}{l}\text { low protein } \\
\text { (LP) }(n=10)\end{array}$} \\
\hline & \multicolumn{8}{|c|}{ weeks } \\
\hline & 12 & 22 & 12 & 22 & 12 & 22 & 12 & 22 \\
\hline Hematocrit $(\%)$ & $\begin{array}{r}46.3 \\
\pm 0.7\end{array}$ & $\begin{array}{r}45.9 \\
\pm 0.7\end{array}$ & $\begin{array}{l}43.1 \\
\pm 0.7 \#\end{array}$ & $\begin{array}{l}41.0 \\
\pm 1.2\end{array}$ & $\begin{array}{l}40.1 \\
\pm 0.7 \dagger\end{array}$ & $\begin{array}{l}37.0 \\
\pm 1.3^{*}\end{array}$ & $\begin{array}{l}45.6 \\
\pm 0.8^{*}\end{array}$ & $\begin{array}{l}44.8 \\
\pm 1.1 *\end{array}$ \\
\hline Total Protein $(\mathrm{g} / \mathrm{dl})$ & $\begin{array}{r}6.5 \\
\pm 0.3\end{array}$ & $\begin{array}{r}6.7 \\
\pm 0.2\end{array}$ & $\begin{array}{r}6.5 \\
\pm 0.2\end{array}$ & $\begin{array}{r}6.5 \\
\pm 0.3\end{array}$ & $\begin{array}{r}6.8 \\
\pm 0.2\end{array}$ & $\begin{array}{r}6.9 \\
+0.2\end{array}$ & $\begin{array}{r}6.5 \\
+0.3\end{array}$ & $\begin{array}{r}6.4 \\
\pm 0.2\end{array}$ \\
\hline Sodium $(\mathrm{mEq} / \mathrm{L})$ & $\begin{array}{l}141 \\
\pm 1\end{array}$ & $\begin{array}{l}141 \\
\pm 1\end{array}$ & $\begin{array}{l}140 \\
\pm 1\end{array}$ & $\begin{array}{l}140 \\
\pm 1\end{array}$ & $\begin{array}{l}140 \\
\pm 1\end{array}$ & $\begin{array}{c}140 \\
\pm 1\end{array}$ & $\begin{array}{l}139 \\
\pm I\end{array}$ & $\begin{array}{l}141 \\
\pm 1\end{array}$ \\
\hline Potassium $(\mathrm{mEq} / \mathrm{L})$ & $\begin{array}{r}3.9 \\
\pm 0.1\end{array}$ & $\begin{array}{r}4.0 \\
\pm 0.1\end{array}$ & $\begin{array}{r}4.0 \\
\pm 0.1\end{array}$ & $\begin{array}{r}4.1 \\
\pm 0.1\end{array}$ & $\begin{array}{r}3.8 \\
\pm 0.1\end{array}$ & $\begin{array}{r}3.9 \\
\pm 0.2\end{array}$ & $\begin{array}{r}4.1 \\
\pm 0.2\end{array}$ & $\begin{array}{r}4.2 \\
\pm 0.1\end{array}$ \\
\hline $\begin{array}{l}\text { Plasma Renin Activity } \\
\text { (ng/ml/hr) }\end{array}$ & $\begin{array}{r}1.8 \\
\pm 0.2\end{array}$ & $\begin{array}{r}2.1 \\
\pm 0.2\end{array}$ & $\begin{array}{r}1.4 \\
\pm 0.2\end{array}$ & $\begin{array}{r}1.7 \\
\pm 0.3\end{array}$ & $\begin{array}{r}1.7 \\
\pm 0.3\end{array}$ & $\begin{array}{r}2.1 \\
\pm 0.3\end{array}$ & $\begin{array}{r}1.5 \\
\pm 0.2\end{array}$ & $\begin{array}{r}1.8 \\
\pm 0.2\end{array}$ \\
\hline Body Weight (g) & $\begin{array}{l}335 \\
\pm 9\end{array}$ & $\begin{array}{r}370 \\
\pm 16\end{array}$ & $\begin{array}{r}328 \\
\pm 11\end{array}$ & $\begin{array}{r}345 \\
\pm 14\end{array}$ & $\begin{array}{r}331 \\
\pm 19\end{array}$ & $\begin{array}{r}340 \\
\pm 17\end{array}$ & $\begin{array}{r}320 \\
\pm 12\end{array}$ & $\begin{array}{r}323 \\
\pm 15\end{array}$ \\
\hline $\begin{array}{l}\text { Urine Volume } \\
\text { (m1/day) }\end{array}$ & $\begin{array}{r}38 \\
\pm 5\end{array}$ & $\begin{array}{r}42 \\
\pm 7\end{array}$ & $\begin{array}{r}38 \\
\pm 5\end{array}$ & $\begin{array}{r}39 \\
\pm 6\end{array}$ & $\begin{array}{r}45 \\
\pm 9\end{array}$ & $\begin{array}{c}84 \\
\pm 12^{*}\end{array}$ & $\begin{array}{r}40 \\
\pm 3\end{array}$ & $\begin{array}{c}28 \\
\pm 5^{*}\end{array}$ \\
\hline
\end{tabular}

Values are expressed as mean \pm SEM. $n=$ number of animals.

\# $\mathrm{p}<0.01$ compared with the corresponding values in CTR

* $\mathrm{p}<0.05$ compared with the corresponding values in STD.

$+\mathrm{p}<0.0$ I compared with the corresponding values in STD. 


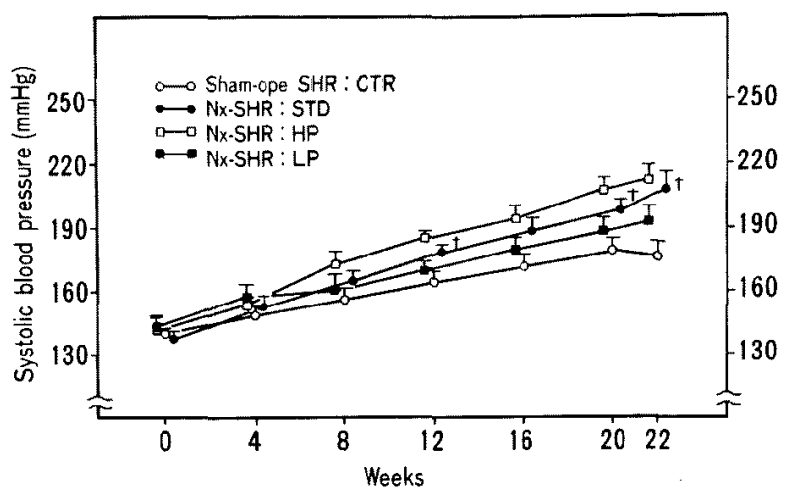

Fig. 1. Effects of alterations of daily protein intake on systolic blood pressure in subtotally nephrectomized spontaneously hypertensive rats (NxSHR). Sham-ope=sham-operated; $\mathrm{CTR}=$ control; $\mathrm{STD}=$ standard diet; $\mathrm{HP}=$ high protein diet; $\mathrm{LP}=$ low protein diet. Values are expressed as mean \pm SEM. $+p<0.01$ compared with the corresponding values in CTR.

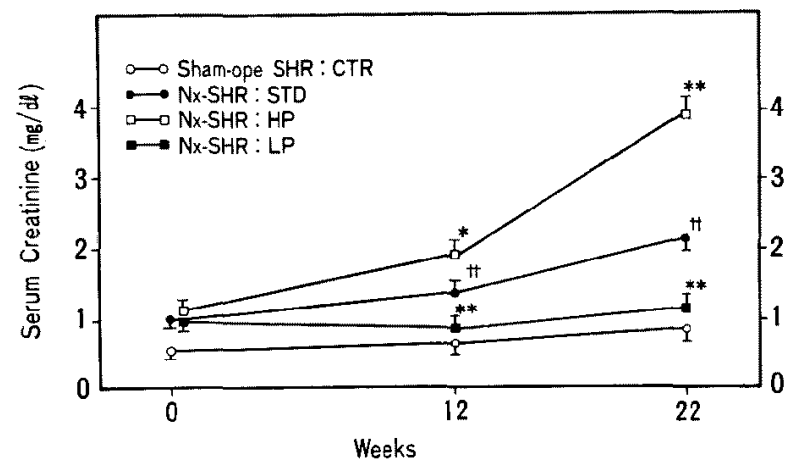

Fig. 2. Effects of alterations of daily protein intake on serum creatinine in subtotally nephrectomized spontaneously hypertensive rats (Nx-SHR). Sham-ope $=$ sham-operated $; \mathrm{CTR}=$ control $; \mathrm{STD}=$ standard diet; $\mathrm{HP}=$ high protein diet; $\mathrm{LP}=$ low protein diet. Values are expressed as mean $\pm \mathrm{SEM}$. $+\dagger \mathrm{p}<0.01$ compared with the corresponding values in $\mathrm{CTR} .{ }^{*} \mathrm{p}<0.05 \mathrm{com}$ pared with the corresponding values in STD. ${ }^{* *} \mathrm{p}<0.01$ compared with the corresponding values in STD.

Serum creatinine was measured after 2 weeks following surgery as a control for a common level of renal insufficiency prior to dietary manipulations. No significant differences were noted between the nephrectomized groups (Fig. 2). After dietary manipulation, the serum creatinine level rose gradually in the HP group. By contrast, the values in the LP group were significantly depressed in reference to the STD group.

Urinary protein excretion in each group is shown in Fig. 3. The rats 


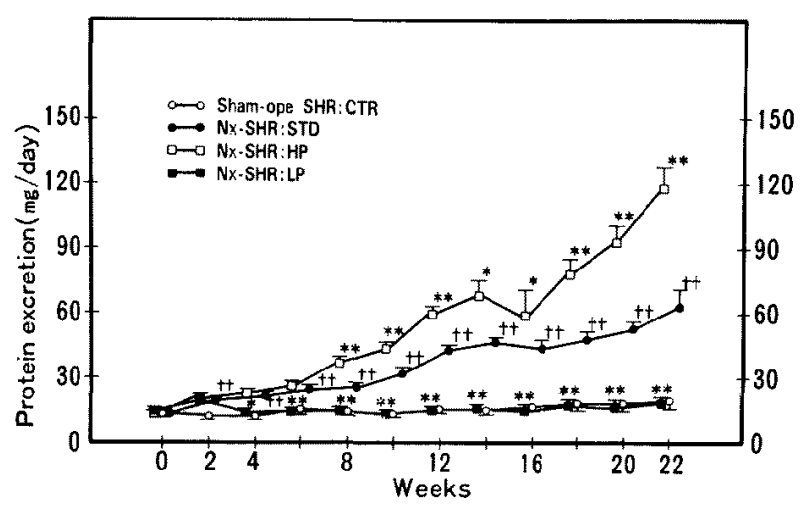

Fig. 3. Effects of alterations of daily protein intake on urinary excretion of protein in subtotally nephrectomized spontaneously hypertensive rats (Nx-SHR). Sham-ope $=$ sham-operated $; \mathrm{CTR}=$ control $; \mathrm{STD}=$ standard diet; $\mathrm{HP}=$ high protein diet; $\mathrm{LP}=$ low protein diet. Values are expressed as mean $\pm \mathrm{SEM}$. t† $\mathrm{p}<0.01$ compared with the corresponding values in CTR. ${ }^{*} \mathrm{p}<$ 0.05 compared with the corresponding values in STD. ** $\mathrm{p}<0.01$ compared with the corresponding values in STD.

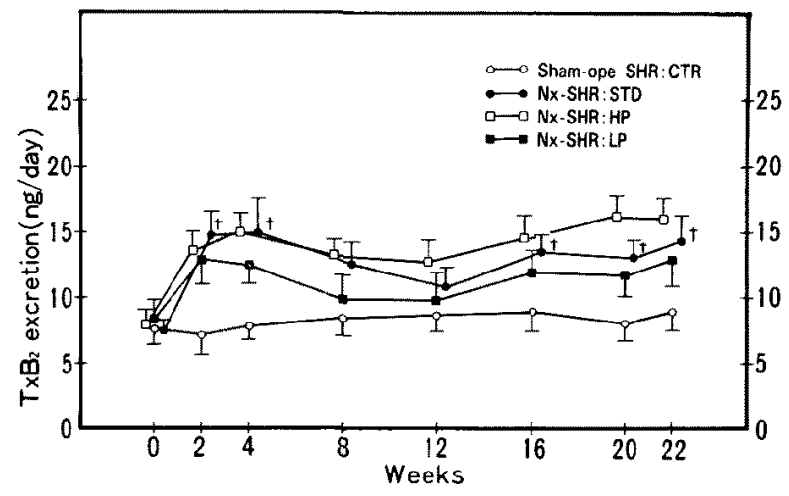

Fig. 4. Effects of alterations of daily protein intake on urinary excretion of $\mathrm{TxB}_{2}$ in subtotally nephrectomized spontaneously hypertensive rats $(\mathrm{Nx}-$ SHR). Sham - ope $=$ sham-operated $\quad \mathrm{CTR}=$ control; STD $=$ standard diet; $\mathrm{HP}=$ high protein diet; $\mathrm{LP}=$ low protein diet. Values are expressed as mean \pm SEM. $+\mathrm{p}<0.05$ compared with the corresponding values in CTR.

in the STD group showed a progressive increase in urinary protein excretion, which appeared to parallel the changes in serum creatinine. The high protein diet yielded the greatest levels of urinary protein while significantly lower levels were observed in the group given a low protein diet. These urinary protein excretions in the latter group did not differ from the CTR group.

In the STD group, urinary thromboxane $\mathrm{B}_{2}$ excretion increased after 


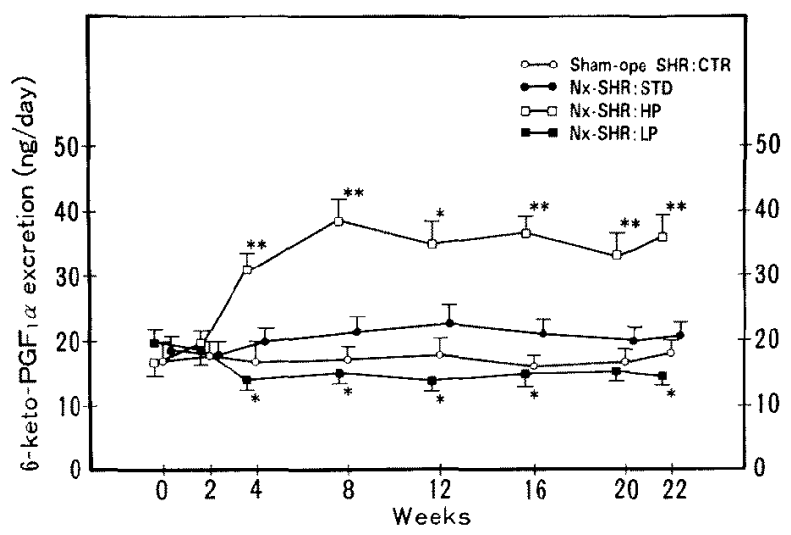

Fig. 5. Effects of alterations of daily protein intake on urinary excretion of 6-keto-PGFl $\alpha$ in subtotally nephrectomized spontaneously hypertensive rats $(\mathrm{Nx}-\mathrm{SHR}) . \quad$ Sham - ope $=$ sham-operated $; \mathrm{CTR}=$ control; STD $=$ standard diet; $H P=$ high protein diet; $L P=$ low protein diet. Values are expressed as mean \pm SEM. $* p<0.05$ compared with the corresponding values in STD. ** $p<0.01$ compared with the corresponding values in STD.

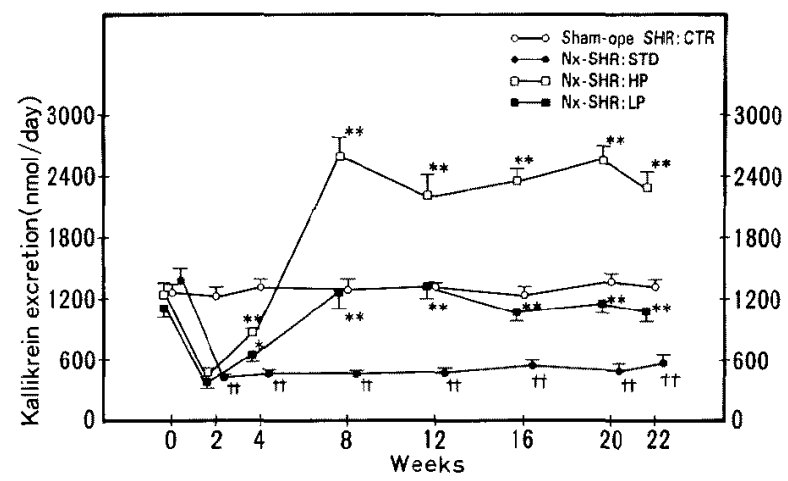

Fig. 6. Effects of alterations of daily protein intake on urinary excretion of kallikrein in subtotally nephrectomized spontaneously hypertensive rats (Nx-SHR). Sham-ope=sham-operated $\quad$ CTR $=$ control $; \quad \mathrm{STD}=$ standard diet; $\mathrm{HP}=$ high protein diet; $\mathrm{LP}=$ low protein diet. Values are expressed as mean \pm SEM. I† $p<0.01$ compared with the corresponding values in CTR. $* \mathrm{p}<0.05$ compared the corresponding values in STD. ** $\mathrm{p}<0.01$ compared with the corresponding values in STD.

subtotal nephrectomy (Fig. 4). However, dietary protein manipulations did not affect urinary thromboxane $\mathrm{B}_{2}$ excretion in hypertensive strains. By contrast, the urinary excretion of 6-keto-PGF $1 \alpha$, a metabolite of $\mathrm{PGI}_{2}$, was not affected by subtotal nephrectomy (Fig. 5). However, the high protein dict increased urinary 6-keto-PGFl $\alpha$ excretion, while the low protein diet decreased these levels throughout the experimental period. 
The values of urinary kallikrein excretion were depressed to about one third of the pre-operative value in the STD group after surgery (Fig. 6). After dietary manipulation, the kallikrein excretion in the HP group increased markedly and continued to increase throughout the experimental period. In the LP group, urinary kallikrein excretions were also moderately increased to the level of the STD group.

\section{Discussion}

The present study has demonstrated that a high protein intake produced a deterioration of renal function without a significant rise in blood pressure after subtotal nephrectomy in SHR. Furthermore, limited protein intake ameliorated the renal damage in hypertensive subjects with renal failure, with serum creatinine falling to nearly normal levels. Both protein loading and high blood pressure are known to exacerbate chronic renal failure. ${ }^{1,2), 7)} \mathrm{Al}$ though protein restriction prevented the aggravation of renal function in the present study, it did not affect the blood pressure elevation. These data imply that dietary protein restriction can reduce the glomerular capillary pressure to a level that prevents damage from the elevated systemic blood pressure. This assumption concerning the effect of dietary protein on renal hemodynamics was in part supported by the recent findings that low protein diet diminished the glomerular capillary pressure and ameliorated the glomerular injury in hypertensive rats undergoing unilateral nephrectomy. ${ }^{18\}, 19}$

After subtotal renal ablation, we found that the urinary thromboxane excretion increased, but that the excretion of the urinary vasodilatory metabolites either did not change (6-keto-PGFl $\alpha$ ) or decreased (kallikrein). It is generally agreed that prostaglandins modify renal and systemic hemodynamics in chronic renal disease. ${ }^{20}$ Administration of cyclooxygenase inhibitor has resulted in the acute deterioration of renal function. ${ }^{21}$ In rats with reduced renal mass, glomerular prostaglandins and thromboxane synthesis are increased ${ }^{22-24)}$ while inhibition of thromboxane synthesis prevents the development of glomerular sclerosis and hypertension. ${ }^{22), 25)}$ Despite the early claims of extra-renal sources, several investigations have concluded that urinary thromboxane $B_{2}$ largely reflects the renal synthesis of its active product, thromboxane $\mathrm{A}_{2}{ }^{20}$ ) Thus, it is assumed that renal thromboxane synthesis is directly corrected with the degree of glomerular injury. Therefore, the severity of renal damage in subtotally nephrectomized rats with protein loading is indicated by the marked elevation of urinary excretion of thromboxane $B_{2}$.

Following dietary manipulation, we observed that a high protein intake 
produced or increased urinary excretion of both 6-keto-PGF1 $\alpha$ and kallikrein, with a gradual deterioration of renal function. By contrast, a low protein diet resulted in a decrease in 6-keto-PGF $1 \alpha$ excretion and a moderate increase in kallikrein excretion. The mechanisms for these dietary effects are unknown. However, the positive correlation between protein intake and urinary 6-keto-PGF $1 \alpha$ excretion throughout the experimental period raises the possibility of the involvement of PGs in this process. It has recently been reported that hyperfiltration is associated with a significant increase in glomerular synthesis of $\mathrm{PGI}_{2}$ in animals with experimental nephrosis which is also reflected in an increase in urinary excretion of 6-keto-PGF $1 \alpha^{23}$ ) In addition, acute protein loading has produced increases in both urinary $\mathrm{PGE}_{2}$ and 6-ketoPGF $1 \alpha$ excretion, while aspirin blocks the augmented glomerular filtration rate induced by protein loading. ${ }^{17), 26)}$ Thus it is possible that the vasodilatory PGs are involved in the glomerular hypertension induced by protein loading in both early and advanced renal failure.

In our renal failure model in SHR, high protein intake resulted in increased urinary kallikrein excretion; a lesser increase was observed for the low protein and standard diet groups. If kallikrein synthesis is determined by the balance between the activation of the renin-angiotensin system and the level of the renal perfusion pressure, ${ }^{27)}$ it seems likely that the high protein diet augments renal kallikrein synthesis by increasing the intraglomerular perfusion pressure without suppressing the renin-angiotensin system. This hypothesis is supported by Kojima et al's ${ }^{28}$ ) recent report of a positive correlation between dietary protein and urinary kallikrein excretion, when high sodium levels suppressed the renin-angiotensin system. However, this hypothesis does not explain the relationship between the low protein diet and kallikrein excretion.

It is not yet clear that the "hyperfiltration theory" provides a general description of the progress of renal disease. Purkerson et al ${ }^{25)}$ suggested that hyperfiltration per se was not directly responsible for the development of glomerular injury because a thromboxane synthetase inhibitor, OKY-1581, prevented the development of glomerulosclerosis despite an increased glomerular filtration rate. They proposed that platelet aggregation plays a major role in the progression of renal injury. One resolution is a synthesis of aspects of these two theories concerning the progression of renal failure. In a model of subtotal nephrectomy, both hyperperfusion (caused by $\mathrm{PGI}_{2}$ and kallikrein) and platelet aggregation (induced by thromboxane) may exacerbate renal damage in animals given a high protein diet. However, since $\mathrm{PGI}_{2}$ is also a potent inhibitor of platelet aggregation, it may counteract the effects of thromboxane. 
In conclusion, the present study demonstrated that in subtotally nephrectomized spontaneously hypertensive rats, a dietary protein overload aggravated the renal function. The animals showed simultaneous increases in urinary 6-keto-PGF $1 \alpha$ and kallikrein excretion. A low protein diet, though, improved renal function, as indicated by diminished urinary 6-keto-PGFl $\alpha$, and increased kallikrein excretion. Therefore, manipulation of dietary protein may alter the natural course of renal diseases in normotensive and hypertensive rats with reduced renal mass.

\section{REFERENCES}

1. Giordano G: Early dietary protein restriction protects the failing kidney, Kidncy Int 28: s66, 1985

2. Neugarten J, Feiner HD, Schacht RG, Baldwin DS: Amelioration of experimental glomerulonephritis by dietary protein restrictions. Kidney Int 24:595, 1983

3. Lumlertgul D, Burke TJ, Gillum DM, Alfrey AC, Harris DC, Hammond WS, Schrier RW: Phosphate depletion arrests progression of chronic renal failure independent of protein intake. Kidney Int 29: 658, 1986

4. Alvestrand A, Ahlberg M, Bergstrom J: Retardation of the progression of renal insufficiency in patients treated with low protein diets. Kidney Int 24: s268, 1983

5. Kenner CH, Evan AP, Blomgren P, Aronoff GR, Luft FC: Effect of protein intake on renal function and structure in partially nephrectomized rats. Kidney Int 27: 739, 1985

6. Hostetter TH, Olson JL, Rennke HG, Venkatachalam MA, Brenner BM: Hyperfiltration in remnant nephrons: a potentially adverse response to renal ablation. Am $\mathrm{J}$ Physiol 241 : F85, 1981

7. Baldwin DS, Neugarten J: Blood pressure control and progression of renal insufficiency. in The Progressive Nature of Renal Disease, ed by Mitch W, Brenner BM, Stein JH, Churchill Livingstone Inc, New York, p 28, 1986

8. Weber PC, Schere B, Held E, Siess W, Stoffel H: Urinary prostaglandins and kallikrein in essential hypertension. Clin Sci 57: s259, 1979

9. Abe K, Seino M, Yasujima M: Studies on renomedullary prostaglandins and renal kallikreinkinin system in hypertension. Jpn Circ J 41: 873, 1977

10. Stork JE, Rahman MA, Dunn MJ: Eicosanoids in experimental and human renal disease. Am J Med $80 \mathrm{~s}(1 \mathrm{~A}): 34,1986$

11. Lowry OH, Rosebrough NJ, Farr AL, Randall RJ: Protein measurement with the folin phenol reagent. J Biol Chem 193: 265, 1951

12. Matsumura Y, Ozawa Y, Suzuki H, Saruta T: Synergistic action of angiotensin II on norepinephrine-induced prostaglandin release from rat glomeruli. Am J Physiol 250: F811, 1986

13. Dray $F$, Charbonnel $B$, MacLauf $\mathrm{J}$ : Radioimmunoassay of prostaglandin $\mathrm{F}_{2} \alpha, \mathrm{E}_{1}$ and $\mathrm{E}_{2}$ in human plasma. Eur J Clin Invest 5: 311, 1975

14. Morita T, Kato H, Iwanaga S, Takada K, Kimura T, Sakakibara S: New fluorogenic substrates for $\alpha$-thrombin, factor Xa, kallikreins, and urokinase. J Biochem 82: 1495, 1977

15. Haber E, Koerner T, Page LB, Kliman B, Purnode A: Application of a radioimmunoassay for angiotensin $I$ to the physiologic measurements of plasma renin activity in normal human subjects. J Clin Endocrinol Metab 29: 1349, 1969

16. Bonsnes RW, 'Taussky HH: On the colorimetric determination of creatinine by the Jaffe reaction. J Biol Chem 158: 581, 1945

17. Levine MM, Kirschenbaum MA, Chaudhari A, Wong MW, Bricker NS: Effect of protein 
on glomerular filtration rate and prostanoid synthesis in normal and uremic rats. Am J Physiol 251: F635, 1986

18. Hostetter TH, Meyer TW, Rennke HG, Brenner BM: Chronic effects of dietary protein in the rat with intact and reduced renal mass. Kidney Int 30:509, 1986

19. Dworkin LD, Feiner HD: Glomerular injury in uninephrectomized spontaneously hypertensive rats: a consequence of glomerular capillary hypertension. J Glin Invest 77: 797, 1985

20. Dunn MJ: Renal prostaglandins. in Renal Endocrinology, ed by Dunn MJ, Williams \& Wilkins, Baltimore / London, p 6, 1983

21. Kimberly RP, Bowden RE, Keiser HR, Plotz PH: Reduction of renal function by newer nonsteroidal anti-inflammatory drugs. Am J Med 64: 804, 1978

22. Stahl RA, Kudelka S, Paravicini M, Schollmeyer P: Prostaglandin and thromboxane formation in glomeruli from rats with reduced renal mass. Nephron 42: 252, 1986

23. Stahl RA, Kudelka S, Helmchen U: High protein intake stimulates glomerular prostaglandin formation in remnant kidney. Am J Physiol 252: F1083, 1987

24. Nath KA, Chmielewski DH, Hostetter TH: Regulatory role of prostanoids in glomerular microcirculation of remnant kidney. Am J Physiol 252: F829, 1987

25. Purkerson ML, Joist JH, Yates J, Valdes A, Morrison A, Klahr S: Inhibition of thromboxane synthesis ameliorates the progressive kidney disease of rats with subtotal renal ablation. Proc Natl Acad Sci USA 82: 193, 1985

26. Kirschenbaum MA, Chaudhari A, Wong MW, Bricker NS: Effect of protein bolus on GFR and glomerular prostanoid synthesis in normal and uremic rats. Kidney Int 29: 339, 1986

27. Mills IH: Kallikrein, kininogen and kinins in control of blood pressure. Nephron 23: 61, 1979

28. Kojima S, Ito K: Effects of protein intake on blood pressure, sodium metabolism, and urinary kallikrein excretion in salt-loaded rats. Nephron 42: 78, 1986 